\title{
Permanence at Risk of Teaching License Courses in the Federal Institutes-Brazil: Tell Me Why You Are Thinking about Dropping Out of Your Course
}

\author{
Rosenilde Nogueira Paniago, Patrícia Gouvêia Nunes, Matias Noll, Celso Martins Belisário, \\ Léia Santiago, Fátima Suely Ribeiro Cunha \\ Instituto Federal Goiano, Rio Verde, Brazil \\ Email: rosenilde.paniago@ifgoiano.edu.br
}

How to cite this paper: Paniago, R. N., Nunes, P. G., Noll, M., Belisário, C. M., Santiago, L., \& Cunha, F. S. R. (2019). Permanence at Risk of Teaching License Courses in the Federal Institutes-Brazil: Tell Me Why You Are Thinking about Dropping Out of Your Course. Creative Education, 10, 735-751.

https://doi.org/10.4236/ce.2019.104055

Received: March 12, 2019

Accepted: April 23, 2019

Published: April 26, 2019

Copyright $\odot 2019$ by author(s) and Scientific Research Publishing Inc. This work is licensed under the Creative Commons Attribution International License (CC BY 4.0).

http://creativecommons.org/licenses/by/4.0/

\begin{abstract}
This article aimed to identify elements that contribute to putting in risk the permanence of students in initial teacher training courses. The research is anchored in studies on avoidance and teaching practices in higher education, being guided by the question: what elements jeopardize the permanence of students in initial teacher training courses? As a procedure for data collection, we used narrative interviews with six students. The results pointed out the motivating actors: the evaluation practice and the teaching methods used by the teachers, the teacher and student relationship, the lack of professional expectation and the difficulty of reconciling work and studies.
\end{abstract}

\section{Keywords}

Initial Teacher Training Courses, Narratives, Permanence at Risk, Federal Institutes. Evasion

\section{Introduction}

This article is about a research whose object of study is the permanence of the students in initial teacher training courses in Biological Sciences and Chemistry of a Federal Institute of Education, Science and Technology-FI. The quality of teacher training courses in Higher Education Institutions-HEI has been a theme that attracts the attention of researchers and educational policies. In spite of the fact that in the last decades there has been an increase in the number of researches that deal with this subject and also of educational programs in terms 
of initial teacher training, effects of which have a positive impact on the quality of initial teacher training education and the permanence of the students, which is the case of the Capes-Pibid program among others. We understand that these actions have not had an impact on the dropout rate index of teacher training courses at High Education Institutions (HEI), which, on the contrary, have increased in recent years.

This research was motivated by the high evasion rate in the initial teacher training courses of the institution, locus of this research. Generally, in the IFs scenario, school dropout is also a problem pointed out by the Federal Court of Auditors-FCA in 2012. In the case of the initial teacher training courses of the region, where this research was developed, they had the worst national performance with only $6.8 \%$ of completion rate (Brasil. Tribunal de Contas da União, 2012).

The information cited justifies the importance of this investigation. We must consider the Federal Institutes, which have a 100-year journey, as a locus of vocational training. However, on what concerns teacher training, our expertise is still in its early stages, especially since 2009 , when Law $\mathrm{N}^{\circ}$. 11.892/2008 changed the former Federal Center of Education into Federal Institutes bearing, now, a university status and implying a new administrative and pedagogical organization and the need to offer $20 \%$ of their opportunities to undergraduate courses.

The motivation for the present research stems from the authors' experience as teachers and researchers dealing specifically with the professional development of teachers involving concepts as knowledge, identity and teaching practices. Since we are teachers working with the initial teacher training courses of a Federal Institute and also members of the research group "EducAção", we have developed several teaching and research projects with a focus on initial teacher training courses and, much to our concern, on their high dropout rates. To illustrate this, in the 2011-2015 period, retention rate ranged from $37.66 \%$ to $43.90 \%$, and the evasion rate varied from $10.04 \%$ to $17.76 \%$ (Instituto Federal Goiano, 2016).

The above paragraphs justify the importance of this research aiming to investigate whose elements contribute to jeopardizing the permanence of the students in these teacher training courses, as well as to pointing out alternatives to reduce this risk. To do so, the following question guides this research: What do the narratives of the teaching license courses say about the participants that jeopardize their stay in the course? In the outline of the article, we opted to present the methodology initially, followed by a brief discussion about the dropout rate in these courses in the IFs and, later, we present the results of the analyses.

\section{Methodology}

In this qualitative research, we initially applied a structured questionnaire with open and closed questions to the students of the initial training courses of the Federal Institute. The questionnaire was forwarded via Google Forms, one of the Google Drive apps, to 80 students who had already failed a course. Among these, 
49 students gave us feedback. When analyzing the data coming from this instrument, we found its fragility in terms of the nuances that interfere in the teaching-learning process of the students and jeopardize their permanence in the course. We, then, decided to collect their narratives, because, the narratives have been part of our trajectory as trainers and researchers, being not only an instrument of data collection, but also a vision of formation that directs our actions, as we have already stated (Paniago, 2016).

The use of narrative interviews as a data collection strategy in this research implied focusing on a small group of subjects, with a view to retrieving their formative memories, learning, life histories, and finally, understanding the various multifaceted interfere with their teaching-learning process and jeopardize their permanence in the course. In this type of research, the use of a large sample makes it impossible to analyze data and the understanding of the various participants that interfere with the object (Paniago, 2016).

Through the narrative interview as an instrument of data collection, we were able to establish a close relationship with the students, in order to listen to their anxieties, their yearnings, to perceive the shining in their eyes, a tear that would sometimes fail to fall; feelings and emotions experienced in the course, impossible to be captured with the use of the questionnaire alone. All narrative interviews were transcribed and sent to the participants before being analyzed.

Thus, in this qualitative study, the autobiographical narrative was constituted as a research approach. Narratives have been widely used in research in the humanities and educational areas. Clandinin \& Connelly (2011) explain that this use is justified because human beings are storytelling organisms, organisms that, individually and socially, live related lives. The narrative studio, therefore, is the studio of the way we humans experience the world.

Through the narratives, the teaching license courses students were able to retrieve memories from the beginning of the course, to bring to the fore memories that marked their trajectory of student life, family, school, social, whether positive or even negative impact on their learning. In this rescue of storytelling, they were selecting the situations that were most significant to them, not exactly as they occur, but in a (re)meaningful way, as Abrahão (2014: p. 68) tells us: "certainly, narratives are re-signification at the moment of the narration given the reconstructive and selective nature of the memory that permeates the relation narrator/listener".

Thus, the teaching license courses students, when narrating, gave new meaning to their history, their experiences, the dilemmas faced in the course that jeopardized their permanence; one of them, at the end of the interview, gave a deep sigh and said: "wow, it was good to talk to you! How good it was to have someone to listen to my problems in this course!" (Ilma, 2018).

The narratives of six teaching license courses students were selected, based on the following criteria: 1) have had more than three failures in the course; 2) be interested in participating in the research; 3) have already thought about drop- 
ping out of the course. The selection was based on the experience in the classroom as teachers and also based on data collected via Google Forms, which signalized the situation of those students at risk of evasion. Experiences and stories of the participants are presented here and represent the following areas: Biological Sciences-Maria, Antonia and Vitória; Chemistry_Ilma, Nara and Elza.

\section{Evasion in the Initial Teacher Training Courses in Federal Institutes: Some Theoretical Perspectives}

According to the Law $\mathrm{N}^{\circ}$. 11,892/2008, the Federal Institutes of Education, Science and Technology-FI are expected to offer a minimum of $20 \%$ (twenty percent) of their entry applications for initial teacher training courses (Brasil, 2008). This requirement is part of the federal government set of measures to stimulate the implementation of initial teacher training courses given the problem of lack of teachers with training to act in basic education.

$60 \%$ (sixty percent) of the initial teacher training courses offered in the Federal Institutes were created after Law 11.892/2008 (Lima, 2014). This fact highlights the rapid expansion in this offer, and the need to investigate how these courses are developed and what causes the permanence of the undergraduate students to be jeopardized. "What is happening is that it is not enough to just target the quantity, but it is also necessary to consider the quality of supply, in several dimensions, among them, the curriculum offered and the conditions of assistance and stay in the courses offered" (Gatti, 2014: p. 34).

As in other institutions, the Federal Institutes have been facing problems with evasion. According to data from the Federal Court of Auditors (Brasil. Tribunal de Contas da União, 2012: p. 10), national completion rates in Federal Institutes, "[...] are $46.8 \%$ for the technical high school, 37.5\% for Proeja (Young and Adult Education), 25, $4 \%$ for the initial teacher training courses, $27.5 \%$ for the Bachelor's degree and $42.8 \%$ for the technological courses". If the completion rates are low for the other courses, the index in the degrees is even lower, since only $27.5 \%$ of the undergraduate students complete the course, this in the national scenario, because, in the region of the research, as already indicated, the completion rate is only $6.8 \%$.

When focusing on the evasion theme, it is important to define its concept. (Dore \& Lüscher, 2011: p. 775) announce that school dropout has been associated with a number of situations, such as "[...] student retention and repetition at school, student leaving the institution, student leaving of the education system, failure to complete a certain level of education, dropping out of school and subsequent return [...]", p. 775.

One of the references on which this paper work is based is the work of the Special Commission for the Study of Evasion in Universities, which defines evasion as "the permanent departure of the student from the course of origin without completing it" (Brasil. ANDIFES/ABRUEM/SESu/ME, 1996: p. 19). Given the diversity of situations that can be considered as evasion, we will focus, in this 
discussion, on avoidance as the non-permanence of the initial teacher training courses, leading the student to abandon it and not to conclude it, that is, we understand evasion as the discontinuity of the student in the course.

There are several elements that influence the permanence of the students that go from pedagogical structure, school practices to external influences, motivation by profession, among others (Dore \& Lüscher, 2011). In turn, the Special Commission of Studies on the Evasion (Brasil. ANDIFES/ABRUEM/SESu/ME, 1996) points to other factors that may contribute to this avoidance:

1) Factors related to individual characteristics of the student, such as ability, disenchantment with the course, lack of information, etc.;

2) Factors external to the institution related to the conditions of the profession, social recognition, social and economic issues of the student, and devaluation of the profession, in the case of initial teacher training courses;

3) Factors internal to the institution: outdated, prolonged curricula; lack of pedagogical training or teacher's lack of interest, insufficient support structure for undergraduate education.

As we may observe in the document, elements related to the personal characteristics of the teaching license students, which are external and internal to the institution, may contribute to school dropout. In terms of external factors and related to the characteristics of the students, the lack of expectation for the profession has been one of the key elements. Indeed, the teaching profession has not been much sought after by young Brazilians, given the social and professional devaluation of the teaching career. Low salaries, working conditions imposed on teachers with a high workload, the sociocultural complexity to be faced daily in the relations established in the school, prevent young people from choosing this profession.

Gatti (2014) states that the teaching career does not exert much influence on young people who are about to finish high school. André et al. (2010: p. 131) also argue that teaching license courses students in the traineeship, when faced with the precariousness of the school, feel insecure about the teaching profession. "[...] The reality of the Brazilian basic school, especially of the public school, scares the students and leads many of them to think of giving up, changing professions", p. 131. On the other hand, Lima \& Machado (2014) affirm that the absence of professional valorization of teachers contributes to the young people not being interested in the profession. According to the authors (Lima \& Machado, 2014: p. 128), all the main elements pointed out in the literature reinforce that "[...] low salaries and precarious teaching conditions are the main causes related to the distance of young people from the teaching profession and also make up the evasion factors in initial teacher training courses".

Still on the external issues, Gatti (2014) warns about the need to consider the sociocultural characteristics of teaching license courses students for their better training and permanence in the course. In terms of aspects internal to the institution, Gatti (2014) points out that one of the factors that influence the perfor- 
mance of the teaching license courses students for and their intention to remain in the course is the fragmentation in disciplines that make up the curricular matrix of the courses and the disconnection between the practices and the future field of work of the trainees-the everyday life of the school of basic education. On the other hand, Paniago (2016) affirms that, in the Brazilian High Education Institutions (HEI), the following formative model prevails "The disciplines of specific content continue to precede the disciplines of pedagogical content and there is little articulation among them; there is no connection between the practices and the knowledge of the training course with the reality of basic education; in some HEIs, the degree is inspired by a baccalaureate course" (Paniago, 2016: p. 80).

If this problem occurs in the context of HEIs, which already have extensive experience with teacher training, this scenario becomes complex in the context of the Federal Institutes, which have started offering teaching license course in the areas of Biology, Chemistry, Pedagogy and Mathematics since 2008. The inexperience of the institution together with the training of teachers, the lack of pedagogical training and inexperience of many teachers with the issues of teaching and research linked to basic education further worsen the situation and contribute significantly to the demotivation of the students to the teaching profession. Nevertheless, it must be taken into account that teachers are selected to work at all levels offered by the institution, that is, from integrated high school to postgraduate courses.

Thus, it was hoped that these institutions would offer continuing education programs to assist teachers in their professional development. However, we observe that the new scenario of the Federal Institutes was not accompanied by teacher training policies, since the offer of pedagogical training in FIs is not visible in order to attend its entire staff. According to data from the Federal Court of Auditors (Brasil. Tribunal de Contas da União, 2012: p. 47) “[...] one-third of the Deans of Undergraduate Studies said that the Institute they work for did not offer a teacher training courses from 2009 to 2011 ".

Machado (2008) points out the need for pedagogical training and another teacher profile when talking about teaching practice of professionals working on professional education. Overcoming the history of fragmentation, improvisation and insufficiency of pedagogical training that characterizes the practice of many professors of today's professional education implies on the recognition that teaching is much more than mere transmission of empirical knowledge or process of teaching content fragmented and theoretically emptied (Machado, 2008).

For the author, it is necessary to have another profile of teachers with the capacity to mobilize new pedagogies, participate in interdisciplinary projects and able to develop the progressive autonomy of the students. In this same direction, Paniago, Sarmento \& Rocha, in research on teaching learning in teacher training in Federal Institutes, point out the importance and necessity of the implementa- 
tion of continuing education programs for initial teacher training courses $(\mathrm{Pa}-$ niago, Sarmento, \& Rocha, 2018).

In general, we believe that this research will contribute to the debate about evasion in teacher training courses in FIs, since there are few productions that focus on this topic. Among others, we want to highlight the paper work organized by Frigotto et al. (2018) whose productions analyze integrated secondary education, including the modality Young and Adult Education. In this rich collection, we drew special attention to the state of the art made by Frigotto et al. (2018) of the academic production on the FIs, consulting theses and dissertations. As a result, they found several surveys with themes focusing on the National Program for the Integration of Vocational Education with the Basic Education on Young and Adult Education, teacher training, local development, curriculum and evasion, however, these works do not focus in initial teacher training courses in the FIs.

From the above, the elements that put in danger the permanence of the students in teacher formation courses will be presented.

\section{Narratives on Risk Staying in Initial Teacher Training Courses}

From the problem of evasion in Federal Institutes-IFs, an action was instituted between the Secretariat of Professional and Technological Education and the Federal Institutes (FIs), for the operationalization of diagnostics, with a view to identifying problems related to evasion, monitoring and intervention actions. Like other Federal Institutes, the institution, the locus of this research, has developed a Strategic Plan for Intervention and Monitoring for Overcoming Evasion and Retention, creating in each of its 12 Campi, follow-up commissions of which we are part. For the implementation of the plan, which aims to "Raise the indices of permanence and success of students, at all levels and modalities of teaching offered in the Federal Institute, through an effective systemic program of action" (Instituto Federal Goiano, 2016: p. 17), all Campi conducted in 2017 and 2018, local diagnoses on evasion and retention in technical and undergraduate courses, with indications of causes and measures to combat evasion.

At the same time, we initially had the results of this institutional diagnosis as the north, and, afterwards, we prepared another questionnaire with closed and open questions and applied with the teaching license course students of the Biological Sciences and Chemistry courses that had already failed in more than one discipline in the course, as reported in the methodology. A total of 49 students answered the questionnaire, 30 females and 19 males. Before presenting the narrative data, we will make a quick presentation of the results of this instrument.

The results indicated that $51 \%$ of the participants thought about dropping out of the course, with the following motivating actors: internally-the evaluative practice and teaching methods used by teachers, the teacher/student relation- 
ship; in external terms-the difficulty of reconciling work and study, little dedication and lack of interest in the subject.

In general, the internal elements were more prominent in the factors that challenge the students to stay in the course, to emphasize the teaching practice and evaluation of the teachers. As for the external elements, the challenge is that most of the graduates are economically disadvantaged and need to work during the day to contribute finances at home, and many travel long distances every day to gain access to the institution.

Also worthy of note were the interest and dedication to studying the discipline, since it was evident that most of the students are more attracted to the specific subjects of the course area- $64.1 \%$ of the respondents said they like the specific subjects of Biology and of Chemistry, $28.2 \%$ said they liked the pedagogical ones, $2.6 \%$ of Biochemistry and other 2.6\% of Mathematics and Physics. The curious thing is that the disciplines that the students like less are those that present the highest index of failure-Biochemistry, in the course of Biological Sciences and Physics and Fundamentals of Calculus, in the course of Chemistry. Nonetheless, the students indicated weaknesses in terms of knowledge of basic education, which leads them to have difficulty, mainly, in the disciplines that involve calculation and knowledge of Chemistry; and in terms of reading, many of them stated that they did not like the pedagogical disciplines due to the amount of readings. André et al. (2010) contribute to this discussion by highlighting that one of the elements that interferes in the practice of the teachers of future teachers is linked to the challenges of reading and writing, as well as lack of knowledge of basic education. Many students enter the High Education Institutions without mastering the essential knowledge of previous schooling.

Concerning the lack of interest in pedagogical disciplines, it was noticed that many attributed the lack of expectation for teaching, or even justified that, despite liking pedagogies, the research instrument did not allow other choices. Since they had to choose one, they chose the specific one, because they were more attuned to this epistemological field. The testimony of a teaching license course corroborates what is being presented: "The system does not let me choose all, so I chose the one that interested me the most". This is understandable, since when choosing a degree course these choices are usually anchored in high school disciplines that have been meaningful to them and/or which have been easy to understand. Of course, it is salutary to highlight the weaknesses of the use of questionnaires for data collection, a fact that referred us to the use of narratives.

We will present the results of the narratives shaped in the following categories: 1) Narratives on motivation for teaching; 2) Life beyond the institution: challenges in reconciling the times of living, studying and working; 3) Internal challenges in the teaching-learning process in initial teacher training courses.

\subsection{Narratives on Motivation for Teaching}

When speaking about the insertion in the chosen course, some of the students 
did not show interest in teaching, "I did not want it! I came here because I was not accepted in the administration course [...] Besides that I could not imagine being a teacher." (Antonia, 2018). In her turn, Ilma states that "what led me to choose the course was because it was a free course at a Federal Institute and that I was able to join" (Ilma, 2018). In the same direction, Maria says

I wanted to major in Agronomy, but as competition was fierce, I thought: "I'm going to apply for Biology" and then I will transfer to my first option. I failed in three subject matters, I insisted on the other term. Then I got involved with the education part, I ended up enjoying it and I decided to stay.

As it is observed, the access to the teaching license course occurred due to a lack of option, and not because of the desire to attend the course and to engage into a teaching profession. This is a very common situation in Brazil, considering the lack of professional and social appreciation, teaching is not placed as the first option in the list of choices of undergraduate courses. Therefore, many young people join the teaching license course for not being able to enter another course, a fact already established (Gatti, 2014). Lima and Machado (2014: p. 125) also point out that "low wages, poor working conditions, lack of safety in schools, lack of social activity and lack of career prospects contribute to fewer and fewer people becoming interested in the profession. Of course, the lack of expectation in relation to teaching is one of the elements that contribute to non-permanence in the course".

It is important to emphasize that the programs of initiation to teaching have contributed to the students to arouse the pleasure for teaching, "I participate in Pedagogical Residence and Pibid; the contact with the school, with the students, their attention motivated me to want to be a teacher" (Maria, 2018). In the same way, Elza says "Pibid made me enjoy being a teacher" (Elza, 2018). In this regard, Paniago, Sarmento \& Rocha (2018) contributes by pointing out the contributions of the Pibid to the learning of teaching and as a motivating element for the students to awaken the taste for the teaching profession and to stay in the course.

\subsection{Life beyond the Institution: Challenges in Reconciling the Times of Living, Studying and Working}

An element that challenges the permanence of the undergraduate students in the course is the difficulty of reconciling life beyond the institution, family, work and study, according to the narratives:

Last semester I was working in 2 jobs [...] it was very complicated but I had no option, either I paid for my bills or studied [...] If I do not work, who will pay for my food? If only teachers could understand that everyone needs to work! Also if teachers could understand that it's not just his/her stuff that we need to study, it would not be necessary to have a psychologist observing us in that room. I took so much caffeine and then I took so much medicine to calm down! At 22, I have to take medicines to calm down! It's not 
just me! If only the teachers knew what they do to us, they would not do that (Nara, 2018).

For me, teachers should think more about us. They need to see that we work all day and come here to college to study (Elza, 2018).

I thought about giving up last year when I got a job [...] working from 7:00 a.m. to 7:00 p.m., and from Sunday to Sunday; so I was overwhelmed with things to do and to study. I had several personal problems in my job and I ended up traumatized. Several problems gave me a very strong depression, I need to go under therapy, I take medication, I thought about giving up (Antonia, 2018).

The narratives of Nara, Maria and Antônia reveal the profile of the teaching license course students of Brazil and the IF; they are generally economically in need, and need to work to continue studying. Scholarships for initial teacher training courses, such as the Pibid and the Pedagogical Residence, help, however, they are insufficient. The students of the Federal Institutes have too much difficulty in reconciling work and study, in short, the time to live, work and study. Nevertheless, many do not reside in the city where the institution is located, and need to travel more than $120 \mathrm{~km}$ daily (round trip) from their cities to the institutes. Of course, the distance traveled every day in addition to sociocultural issues, the challenges of reconciling the time of living, studying and working, are factors that influence too much the learning performance of the students in the initial teacher training courses. In this regard, Gatti (2014: p. 49) alerts us to the observance of these questions and affirms that "there is a differentiated contingent of students who have been looking for undergraduate courses whose characteristics need to be considered by HEIs if they wish to promote inclusion of all with formative quality".

In addition to the difficulties in continuing studying, Nara signals emotional problems leading her to use medications to calm her down. Even in the midst of tears, she says that not only she is in need of medication, but also other colleagues and one of them has even threatened suicide,

Last week, a student tried to kill himself; I think he is engaged in a semester before mine, seventh term. He took a test, failed it, couldn't reach the average, now he said he would fail. It must be the fifth time he has failed and gathers personal problems, it seems that his mother left his father. They lost their house (Nara, 2018).

The narratives tell us about how affective and emotional issues interfere in the teaching-learning process and demand pedagogical sensitivity from the teachers to understand that the students do have a life beyond the confines of the classroom, a life that is full of joys, but also challenges in terms of family, economy and socio-cultural problems. As Paniago (2017: p. 57) states, current times demand "... new demands, calling on teachers to solve cognitive, psychological, affective and moral situations." For the author (Paniago, 2017: p. 117), "teaching 
is a profession that deals with people; the students are human beings and not machines that can be processed technically and mechanically as if there had no feelings, affectivity or different ways of learning". In this sense, it is important that teachers consider the affective and sociocultural aspects of the students.

Next, we will present other factors in terms of internal order of the institution highlighted by the teaching undergraduate students that influence in the teaching-learning process and cause them to think about giving up the course.

\subsection{Difficulties in the Learning Process}

In terms of classroom learning in the institution, the narratives indicate elements that challenge them to remain connected to the course and linked to the didactic components of the class, to highlight the teaching methods of teachers, the evaluation form and the teacher and student relationship.

To begin with, the students point out the disciplines that require longer studying hours. In Biological Sciences we may quote: Physics, Biochemistry and Calculus: "When I started studying Biology, I tried to get away from the calculations, too. When I joined the course of Biology I failed in Biochemistry, Physics and Cell Biology" (Vitória, 2018); on what concerns the Chemistry Course, the highlighted disciplines are Calculus and Physics "I failed many times, especially, in calculus that is very difficult" (Elza, 2018). Nara also states "I failed Physics, because it is really difficult" (Antonia, 2018). Also Nara announces: "I had lots of difficulties in Physics, because the teacher did not really teach" (Nara, 2018).

The teaching methods of different teachers were highlighted in the narratives as elements that discourage permanence in the course:

My difficulty is with teachers who have just left a doctorate or master's degree and think they know everything but cannot explain it right $[\ldots]$ also what kills with me in any discipline is the teacher using only one example teaching method, and even with the whole class getting bad grades, failing the subject matter and still the teacher continues with the same method (Vitória, 2018).

There is a teacher who runs through the content; I think the important thing is not quantity but quality; sometimes there are 3 contents for a test and we do not learn any; as a consequence the whole class gets a bad grade and the teacher gets angry with the group (Maria, 2018).

It is simply a "pouring out of content", teacher lecturer, teacher that gets to class with a slide show presentation and says: you already know this, don't you? So I'm going to move on to the next one, I'm not crazy to tell the teacher that I do not know, I stay there, it just goes by and I stay here agreeing with him and taking notes of topics, to get home, go google search and watch a teacher there teaching (Nara, 2018).

As we have seen, the narratives denounce the use of slide show presentations as the main didactic strategy used by teachers. In the same direction, Elza signalizes: "Will you only use slide presentations! The students spend all day working, 
get to college tired and sleepy and still have to watch slides, this is killing us! [...] When you get to slide 10 you no longer understand anything" (Elza, 2018).

Nonetheless, it is signaled by the teachers that teachers do not observe their time and their way of learning. As Nara points out, it is easier to learn content on a website than in the classroom. Also Antónia corroborates when pointing out that one of her difficulties is with "Dull classes, always the same teaching methods (slide). And the teachers lack of motivation in getting students to be engaged in learning the subject' (Antonia, 2018).

Still on methods, Ilma says she gave up on two subjects because she did not understand how teachers teach the classes. "I gave up on two subjects because the teachers did not show the minimum didactics needed to explain the content and I felt that I could not do the as it would not be able to absorb anything, since I already had difficulties in these matters [...]" (Ilma, 2018).

In general, the narratives denounce the lack of pedagogical didactic knowledge of the teachers. Gatti (2014: p. 44) warned that "HEI professors who work in initial teacher training courses in different undergraduate courses, for the most part, did not have didactic training and were not recruited with the prospect that they will act or may act as teacher trainers". According to Vitória "Many teachers do not analyze their teaching methods, just because they master the content it does not mean that he/she can convey it clearly to the students" (Vitória, 2018).

Of course, mastering the content of the training area does not mean that the teacher will develop a teaching that favors the students' learning, considering that teaching is a profession of human interaction that implies the teacher to use different areas of expertise. In this sense, Paniago (2017) highlights the knowledge necessary to carry out teaching, which includes the knowledge of the area of formation, the pedagogy of content, knowledge about the various Sciences of Education, about the way students learn and their context, about reflection and research practices. Thus, teaching is a complex profession that involves the mobilization of this knowledge with a view to improving the quality of the teaching-learning process. For Paniago (2017)

It is not enough to know without being; it is not appropriate to have all the dimensions of the knowledge described above without the sensitive, loving posture, the affective sensitivity to the student's understanding as a person and their different ways of being and learning-understanding and respect for differences, with life and with nature (p. 80).

It is necessary, therefore, in addition to having sensitivity and affectivity that the teachers use different didactic strategies in the classroom so that the students have a better understanding of the concepts worked. The constant use of the same strategy, such as the use of Power Point slides, in addition to monotonizing the classes, places the students in the condition of mere spectators, with a passive attitude towards their own learning. André et al. (2010: p. 131) contribute by stating that "the task of motivating students to engage in teaching requires the 
teacher to mobilize different knowledge, to use different didactic strategies, to review their beliefs and principles, and to rethink their role as a teacher trainer". Nonetheless, we must bear in mind that we are talking about a initial teacher training course. In case the students are having this learning perspective, what knowledge will they mobilize in the classroom as future teachers?

In this same line of thought, students denounce that the teaching practices of some teachers do not match the ones of a trainer:

We are here to learn how to teach, because one day we will be teachers. But we have few pedagogical materials, and the specific ones would have to help us on how to teach such content to students. It is not what happens, therefore, we have teachers who only provide us with contents and tests (Ilma, 2018).

The teachers must stop and analyze that we are there to learn, we are seeking knowledge [...] if I leave here without knowing anything, what kind of teacher will I be? (Antonia, 2018).

When there are engineers in the class, they talk... I can charge more, they focus on the calculation and forget about the degree; they forget that they are training a teacher; my course tends to a bachelor degree more than to an undergraduate one (Nara, 2018).

The narratives denounce the lack of preparation of some of the trainers to act in the initial teacher training courses, since they are teaching classes in initial courses of future teachers and that will leave deep marks in terms of didactic posture in the classroom and in the way of relating with the students. In this direction, Gatti (2014) also states that undergraduate teaching students denounce the unpreparedness of some of the trainers on issues alluding to the teaching profession.

The narratives of Nara, Ilma and Antonia draw attention when they warn students that they are attending an initial teacher training course, and not a baccalaureate one. In this case, the focus should be on the educational practices of basic education and not just on specific contents. According to Gatti (2014)

In Brazil, undergraduate courses prove to be watertight, and also segregate training in the area of specific knowledge in the area of pedagogical knowledge, dedicating a small part of their curriculum to professional teaching practices, school, didactic and of school learning (p. 38).

When it comes to an initial teacher training course, it is fundamental that teachers observe how students learn and mobilize different didactic strategies, evaluation tools and dialogues with students, valuing their way of thinking. In this direction, the relation between teacher and student also places itself as an important element that (un) motivates the students to continue enrolled in the course. In this situation, the narratives, in general, point out that many of the teachers are concerned with the students. However, some do not facilitate dialogue, as Nara says: 
If we had the freedom to ask questions. when we are going to have our questions answered, he asks, but you did not learn that? Then you blame yourself and the shame is huge in a room with 50 people! You feel so small that you have no further questions. One day, a teacher asked me what my grade was on ENEM and I answered 798, so he said: I do not know how you got that grade! This discourages us! (Nara, 2018).

Vitória, representing the other students, also asked that there should be more: "Respectful dialogues between teachers and students, and more methods of evaluation. A teacher should be more tranquil when teaching a content. He/She should listen to the students more!" (Vitória, 2018).

In addition to the teaching methods and the teacher-student relationship, the evaluation process is denounced as a crucial element that jeopardizes the permanence of the students in the course, considering that sometimes it is used as a threat. Based on that, we may consider what Nara says "the first day the teacher entered the room and said: only $3 \%$ of my students are approved! I remember it clearly" (Nara, 2018). In the same direction, Antonia points out: "The teacher enters the classroom and writes on the first day of class. I assign only 3 tests during the semester, so you have to study. That already gives me a shock, because if I go wrong in the first one how can I recover?" (Antonia, 2018). Nevertheless, the narratives indicate that many teachers use few assessing instruments, "in some subjects the assessment instrument was only a written test" (Maria, 2018). Nara also points out the anguish about the evaluation of a teacher

The teacher gave 2 tests in the semester; the first test had 2 questions, each worth 50 and the last one was composed of 2 questions with a total score of 50 ; the entire theory studied was evaluated in 2 questions. I remember once answering a whole test and my grade was zero, by mistake, because I missed a comma [...] It took me more than three hours to do that test, and in the last question the response was 6 and I wrote (Nara, 2018).

Nara, with tears in her eyes, explains that there were countless times when she studied hard thinking that she would perform well and, in the end, she had a zero in the test with this particular teacher. "[...] I happened to arrive in the classroom and say I was going to do very well because I missed classes to study, I did not come to the IF because I was going to study for the test. I paid three hundred dollars for a private tutor, I got the list, the guy solved the whole list with me and I got here and got zero in the test" (Nara, 2018). Elza also states how much a failure discourages "It discourages a lot, having to do the same subject several times, I have a colleague who gave up the course because she was going to do the same subject for the fourth time and she studied a lot' (Elza, 2018).

Indeed, the narratives point out fundamental questions to be rethought in the institution that ranges from changes in teaching practices to the assessment process of trainers. The use of the evaluation is not certain, fulfilling its intention. On the contrary, it has been classificatory and excluding, thus impacting 
the permanence of the students. Therefore, we advocate an evaluation practice based on the principle of investigation, so that the teacher may carry out the accompaniment of the student over time and his/her teaching practice. Paniago (2017) contributes with this topic by highlighting several possibilities of didactic strategies that teachers can mobilize in the classroom with a view to developing their evaluation teaching practice, not only focusing on an assessment tool or even on the exclusive use of lectures or by means of some other technological artifact.

\section{Final Considerations}

Initially, we highlight the complexity of identifying the elements that jeopardize the permanence of the students of the curricula of initial teacher training, of the Federal Institute of Education, locus of this research, considering that they involve personal situations of the students, internal and external to the institution. In so we clarify that the data discussed here are contextual and may not represent the situation of the other FIs. Nonetheless, we emphasize that when we use narrative interviews as a data collection strategy, we focus on a small group of subjects, with a view to recovering their formative memories, learning, life histories, and aspects that interfere in the teaching-learning process and jeopardize their permanence in the course. In this type of research, the use of numerous samples makes it impossible to analyze data and the understanding of the various participants that interfere with the object.

In general, we try to identify the main elements that contribute to jeopardizing the permanence of the students in the initial teacher training courses, causing them to give up.

Telling us why they are thinking of giving up the curses, the girls signaled as external elements the difficulty of reconciling work and study and the expectation in relation to the teaching profession. As internal elements, the emphasis was on teaching practices in the teachers' classroom-teaching methods and evaluation-and the relation between teacher and student. It is important to emphasize that the actors highlighted in the narratives are aligned with those raised by the questionnaire, except for the specificities alluding to internal issues, which detailed the details in the narratives.

The data point mainly to the internal factors, since some of the students, even though they did not initially have expectations regarding teaching, the programs in which they participated, highlighting the Pibid and Pedagogical Residence, motivated them to remain in the course. In this perspective, the challenges in terms of reconciling work and study could even be overcome if, in case, the trainers would pay special attention to their problems and to the complexities faced to remain in the course.

In this way, the lack of professional expectation, the difficulty to reconcile living, studying and working, together with the teaching practices of teachers are key elements that contribute to the failure and jeopardize the permanence of the 
teaching undergraduate students in the courses. These features are sometimes consubstantiated in homogeneous, repetitive methodologies that do not contemplate the different forms of learning, study/work relationship and socio-cultural situations, in which the students are immersed.

Finally, the research signaled the importance of giving voice to the students. Considering the complexity of the factors that influence permanence, it is necessary to debate the topic and face it collectively with the participation of the entire educational community, so that all persons involved may present their ideas, indicating possible ways to mitigate the problem. One of the possibilities is to expect the institution to offer continuing educational programs to support teachers in their professional development, so as to better develop their teaching practices and promote spaces for reflection and sharing of knowledge. Although, institutionally, the FIs are initiating the implementation of training proposals for teachers, they are timid and do not include all teachers. What we have observed is that in the locus of research, there are no spaces of continuous formation, as we have already stated (Paniago, Sarmento, \& Rocha, 2018); on the contrary, a culture of isolation prevails, which does not favor the collective search for actions that improve the quality of teaching and reduce evasion in the institution.

\section{Acknowledgements}

To the Goiano Federal Institute for the support.

\section{Conflicts of Interest}

The authors declare no conflicts of interest regarding the publication of this paper.

\section{References}

Abrahão, M. H. M. B. (2014). Fontes orais, escritas e (áudio)visuais em pesquisa (auto)biográfica: Palavra dada, escuta (atenta), compreensão cênica. O Studium e o punctum possíveis. In M. H. M. B. Abrahão, I. F. S. Bragança, \& M. S. Araújo (Eds.), Pesquisa auto (biográfica): Fontes e questões (pp. 57-58). Curitiba: CRV. https://doi.org/10.24824/978854440185.9

André, M. et al. (2010). O trabalho docente do professor formador no contexto atual das reformas e das mudanças no mundo contemporâneo. Revista Brasileira de Estudos Pedagógicos, Brasília, 91, 122-143.

Brasil. ANDIFES/ABRUEM/SESu/ME (1996). Comissão Especial de Estudos sobre a Evasão nas Universidades Públicas Brasileiras. Diplomação, Retenção e Evasão nos Cursos de Graduação em Instituições de Ensino Superior Públicas. http://www.andifes.org.br/wp-content/files_flutter/Diplomacao_Retencao_Evasao_Gra duacao_em_IES_Publicas-1996.pdf

Brasil (2008). Lei 11.892, institui a Rede Federal de Educação Profissional, Científica e Tecnológica, cria os Institutos Federais de Educação, Ciência e Tecnologia, e dá outras providências. Brasília.

Brasil. Tribunal de Contas da União (2012). Secretaria de Fiscalização e Avaliação de Programas de Governo Rede Federal de Educação Profissional, Científica e 
Tecnológica. Brasília: Relatório de auditoria.

Clandinin, D. J., \& Connelly, F. M. (2011). Pesquisa Narrativa: Experiência e história em pesquisa qualitativa. Tradução: Grupo de Pesquisa Narrativa e Educação de Professores ILEEI/UFU, Uberlândia: EDUFU.

Dore, R., \& Lüscher, A. Z. (2011). Permanência e Evasão na Educação Técnica de Nível Médio em Minas Gerais. Cadernos de pesquisa, 41, 772-788. https://doi.org/10.1590/S0100-15742011000300007

Frigotto, G. et al. (2018). O "estado da arte" das pesquisas sobre os IFs no Brasil: A produção discente da pós-graduação de 2008 a 2014 . In F. Gaudêncio (Ed.), Institutos Federais de Educação, Ciência e Tecnologia Relação com o ensino médio integrado e o projeto societário de desenvolvimento (pp. 83-112). Rio de Janeiro: UERJ, LPP.

Gatti, B. A. (2014). Formação inicial de professores para a educação básica: Pesquisas e políticas educacionais. Estudos em Avaliação Educacional, 25, 24-54. https://doi.org/10.18222/eae255720142823

Instituto Federal Goiano (2016). Plano estratégico de intervenção e monitoramento para superação da evasão e retenção.

Lima, E., \& Machado, L. (2014). A evasão discente nos cursos de licenciatura da Universidade Federal de Minas Gerais. Educação Unisinos, 18, 121-129. https://doi.org/10.4013/edu.2014.182.02

Lima, F. B. G. (2014). A formação de professores nos institutos federais de educação, ciência e tecnologia: Um estudo da concepção política. Natal: IFRN.

Machado, L. R. S. (2008). Diferenciais inovadores na formação de professores para a educação profissional. Revista Brasileira da Educação Profissional e Tecnológica, Brasília, 1, 8-22. https://doi.org/10.15628/rbept.2008.2862

Paniago, N. R. (2017). Os professores, seu saber e o seu fazer: Elementos para uma reflexão sobre a prática docente. Paraná: Editora Appris.

Paniago, R. N. (2016). Contribuições do Programa Institucional de Bolsa de Iniciação para a Aprendizagem da Docência Profissional, Tese de Doutoramento Universidade do Minho, Braga.

Paniago, R., Sarmento, T., \& Rocha, S. (2018). O Pibid e a inserção à docência: Experiências, possibilidades e dilemas, Educação em Revista. Belo Horizonte, 34, 1-31. http://dx.doi.org/10.1590/0102-4698190935 